\title{
PARTICIPATION OF MUSCARINIC RECEPTORS ON SPLANCHNIC-ADRENAL TRANSMISSION IN THE RAT
}

\author{
Toshio YOSHIZAKI \\ Shionogi Rescardh Laboratorl, Shionogi \& Co., Lrd., Thkushima-ku, \\ Osaka, Japan
}

Accepted May 2, 1973

\begin{abstract}
Studies were performed on the nature of splanchnic-adrenal transmission in the rat. Marked adrenaline secretion was ohserved after clectrical stimulation of the greater splanchnic nerve, and optimum voliage and frequency in a train of tetanus of $1 \mathrm{msce}$ square for $10 \mathrm{sec}$ at $10 \mathrm{sec}$ intervals were $5 \mathrm{~V}$ and $20 \mathrm{c} / \mathrm{sec}$ respectively. HexamethoniLin bromide caused nuaked inhibition of the response to the nerve stimulation and at a dose of $1 \mathrm{mg} / \mathrm{kg}$, the inhibition rate was about $75 \%$. Atropine also prevented adrenaline secretion in response to the tetanus, but the inhibitory action of $5 \mathrm{mg} / \mathrm{kg}$ of atropine sulfate was equipotent to that of only $0.2 \mathrm{mg} / \mathrm{kg}$ of hexamethonium bromide. Five mg/kg of atropine sulfate after $i . v$. injection of 1 $\mathrm{mg} / \mathrm{kg}$ of hexamethonium hromide caused appreciable inhibition of the residual adrenaline release by the stimulation of splanchnic nerve. It is concluded that transmission of impulses throngh muscarinic receptors may occur in the adrenal medulla of the rat, though this type of transmission is less prominent than that through nicoinic receptors.
\end{abstract}

After Feldberg et al. (1) demonstrated that large doses of nicotine failed to block completely the pressor effects of stimulating the splanchnic nerve, but that the residual response was reduced hy atropine in the cat, there have been a few reports presenting evidence that muscarinic action plays a part in cholinergic transmission in the adrenal medulla $(2,3)$. No reference was found. however, concerning the nature of the transmission of impulses in the adrena! medulla of the rat.

The present paper demonstrates the nature of splanchnic-adrenal transmission in this species.

\section{MATERIALS AND METHODS}

Experiments were carried out with male rats of Splague-Dawley strain weighing 400$600 \mathrm{~g}$. Rats were anesthetized with an i.p. injection of $50 \mathrm{mg} / \mathrm{kg}$ of Nembutal sodium, cannulated into the saphenous vein for drug injection and transfusion of fluids. The abdomen was incized using a horizontal incision. The left greater splanchnic nerve was ligated as far as possible from the adrenal and cut beyond the knot. The animal was then given heparin i.v. The left renal vein was iigated at both terminals and cannulated for collection of adrenal-venous blood. The wo cannulas were then connected to each other. The dissected splanchnic nerve was placed on a bipolar silver electrode and the abdominal cavity was filled with sufficient paramin oil to cover the nerve.

For electrical stimulation. 15 ten-sec periods of rectangular pulses $(1 \mathrm{msec}$ dura- 
tion, $5 \mathrm{~V}$ and $20 \mathrm{c} / \mathrm{sec}$ ) at $10 \mathrm{sec}$ intervals were applied 5 min after a conditioning tetanus ( 3 periods of the same pulses as test tetanus). A control sample of adrenal-venous blood was collected for $10 \mathrm{~min}$ after the onset of the stimulation, then drugs were injected i.v. Five min after drug administration, the same electrical stimulation was applied again and a test specimen of adrenal-venous blood was collected in addition to a control sample. The specimens were immediately centrifuged. After centrifugation, plasma and cell volumes were recorded. Determination of adrenaline in the plasma was performed by the method described in a previous paper (4).

During the collection of adrenal-venous blood, Ringer's solution containing $0.1 \%$ of glucose was transfused at a rate of 2.5 to $3.0 \mathrm{ml}$ per $10 \mathrm{~min}$.

Hexamethonium bromide (Methobromin-Yamanouchi) (C6) and atropine sulfate (Merck) were dissolved in $0.9 \%$ saline and $0.5 \mathrm{ml} / \mathrm{kg}$ of the solutions were injected into the saphenous vein.

\section{RESULTS}

Adrenaline secretion from rat adrenal medulla in response to stimulation of the splanchnic nerve was studied at first. At a fixed frequency of $20 \mathrm{c} / \mathrm{sec}$, the voltage of stimulation was changed from $1 \mathrm{~V}$ to $7.5 \mathrm{~V}$. Adrenaline release reached a maximum at about $5 \mathrm{~V}$ and then showed a plateau (Fig. 1). In the next experiment, the frequency was changed from $5 \mathrm{c} / \mathrm{sec}$ to $80 \mathrm{c} / \mathrm{sec}$ at the voltage of $5 \mathrm{~V}$. The adrenaline output in response to repeated tetanus reached a maximum at about $20 \mathrm{c} / \mathrm{sec}$ (Fig. 2). The adrenaline output caused by the first stimulation was compared with that in response to a second stimulation after a 5 min interval, in the same individual. The two values showed no significant differences (Table 1).

Inhibitory effects of $\mathrm{C} 6$ and atropine on adrenaline output in response to the stimulation of the splanchnic nerve are demonstrated in Table 2. C6 markedly prevented adrenaline secretion and inhibition was almost complete at a high dose of $25 \mathrm{mg} / \mathrm{kg}$. In-

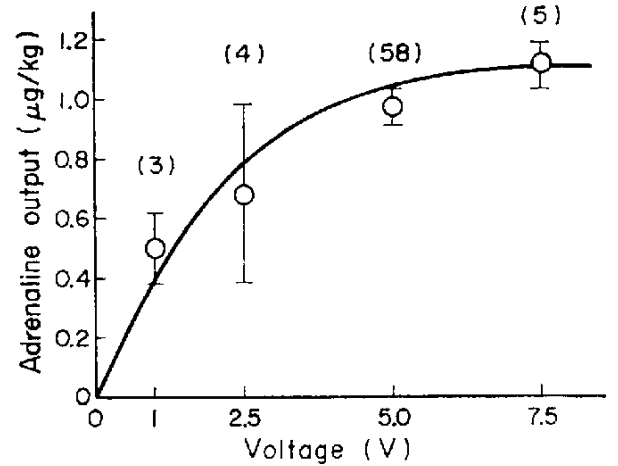

Frg. 1. Optimum voltage of electrical stimulation of the splanchnic nerve for adrenaline release from rat adrenal medulla. Each point is the mean \pm S.E. Number of experiments in brackets.

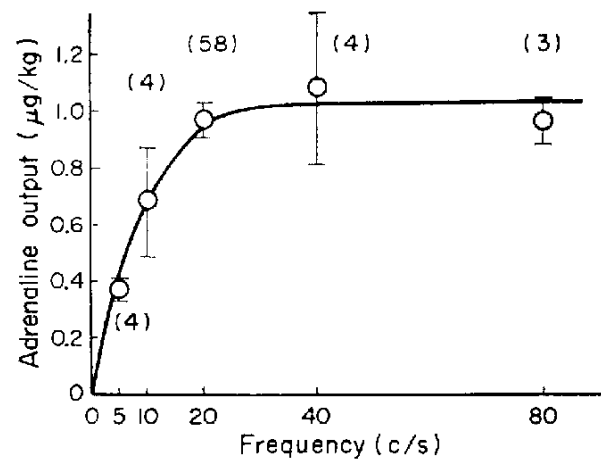

FIG. 2. Optimum frequency of electrical stimulation of the splanchnic nerve for adrenaline release from rat adrenal medulla. Each point is the mean \pm S.E. Number of experiments in brackets. 
TABLE 1. Comparison between adrenaline output from rat adrenals in response to first train and second train of stimulation of splanchnic nerve.

\begin{tabular}{cccc}
\hline $\begin{array}{c}\text { Voltage } \\
(\mathrm{V})\end{array}$ & $\begin{array}{c}\text { Frequency } \\
(\mathrm{c} ; \mathrm{sec})\end{array}$ & $\mathrm{n}$ & $\begin{array}{c}\text { Adrenaline output } \\
\text { (2nd }\end{array}$ \\
& 5 & 4 & $104.5 \pm 8.0$ \\
& 10 & 4 & $100.5 \pm 9.9$ \\
5.0 & 20 & 6 & $96.5 \pm 3.1$ \\
& 40 & 4 & $98.8 \pm 5.4$ \\
& 80 & 3 & $102.4 \pm 12.4$ \\
\hline
\end{tabular}

Two trains of tetanus (15 ten-seconds of rectangular pulses, $1 \mathrm{msec}, 5 \mathrm{~V}$, $20 \mathrm{c} / \mathrm{sec}$, at $10 \mathrm{sec}$ intervals) were applied at a $5 \mathrm{~min}$ interval in the same animal.

Adrenaline output values represent the mean \pm S.E.

TABLE 2. Effects of atropine and hexamethonium on adrenaline release from rat adrenal in response to electrical stimulation of splanchnic nerve.

\begin{tabular}{|c|c|c|c|c|c|}
\hline \multicolumn{2}{|c|}{ Treatment $(\mathrm{mg} / \mathrm{kg})$} & \multirow[b]{2}{*}{$\mathrm{n}$} & \multicolumn{3}{|c|}{ Adrenaline output } \\
\hline $\begin{array}{l}\text { Hexamethonium } \\
\text { bromide }\end{array}$ & $\begin{array}{l}\text { Atropine } \\
\text { sulfate }\end{array}$ & & $\begin{array}{r}\text { Control } \\
(\mu \mathrm{g} / \mathrm{kg})\end{array}$ & $\begin{array}{l}\text { Treated } \\
(\mu \mathrm{g} / \mathrm{kg})\end{array}$ & $\%$ of control \\
\hline 0 & 0 & 6 & $1.23 \pm 0.05$ & $1.18 \pm 0.06$ & $96.5 \pm 3.1$ \\
\hline 0 & 1.0 & 5 & $1.47 \pm 0.17$ & $1.09 \pm 0.13$ & $73.9 \pm 4.7^{(3)}$ \\
\hline 0 & 5.0 & 3 & $1.12 \pm 0.06$ & $0.70 \pm 0.13^{(1)}$ & $61.6 \pm 8.3^{(3)}$ \\
\hline 0.2 & 0 & 3 & $0.77 \pm 0.17$ & $0.48 \pm 0.10$ & $62.4 \pm 1.3^{(3)}$ \\
\hline 1.0 & 0 & 6 & $0.97 \pm 0.13$ & $0.24 \pm 0.04^{(2)}$ & $24.0 \pm 1.5^{(3)}$ \\
\hline 1.0 & 5.0 & 6 & $0.79 \pm 0.10$ & $0.12 \pm 0.02^{(2)}$ & $14.3 \pm 1.1^{(3),\langle 4\rangle}$ \\
\hline 5.0 & 0 & 6 & $1.12 \pm 0.15$ & $0.12 \pm 0.02^{(2)}$ & $12.6 \pm 2.8^{(3)}$ \\
\hline 5.0 & 5.0 & 5 & $0.90 \pm 0.13$ & $0.05 \pm 0.01^{(2)}$ & $5.7 \pm 1.5^{(3)}$ \\
\hline 25.0 & 0 & 3 & $1.03 \pm 0.24$ & $0.09 \pm 0.03^{(3)}$ & $8.2 \pm 1.5^{(3)}$ \\
\hline
\end{tabular}

Atropine was injected i.v. subsequent to i.v. administration of hexamethonium.

Adrenaline output values represent the mean \pm S.E.

(1) Significantly different from the control at $\mathrm{P}<0.05$.

(2) Significantly different from the control at $\mathrm{P}<0.01$.

(3) Significantly different from the group with no drug at $\mathbf{P}<0.01$.

(4) Significantly different from the hexamethonium bromide $(1.0 \mathrm{mg} / \mathrm{kg})$ treated group at $\mathrm{P}<0.01$.

hibition by atropine sulfate was, however, not more than 25 to $40 \%$ of control at doses of 1.0 and $5.0 \mathrm{mg} / \mathrm{kg}$.

Injection of $5.0 \mathrm{mg} / \mathrm{kg}$ of atropine sulfate subsequent to C6 administration caused appreciable inhibition of the residual adrenaline release by stimulation of splanchnic nerve. The inhibition was statistically significant at $1 \mathrm{mg} / \mathrm{kg}$ of $\mathrm{C} 6$.

\section{DISCUSSION}

The response of cat adrenal medulla to splanchnic stimulation was investigated in detail by Marley and Paton (5). Few observations have however been made in the rat. Prior to investigation of the muscarinic component of splanchnic-adrenal transmission, 
the output of adrenaline from rat adrenal medulla in response to stimulation of the splanchnic nerve was studied, and optimal condition of electrical stimulation was set at $5 \mathrm{~V}$ and $20 \mathrm{c} / \mathrm{sec}$.

In this experiment atropine inhibited adrenaline secretion caused by splanchnic nerve stimulation. It has been reported that atropine has a ganglionic blocking effect (6). However, $5 \mathrm{mg} / \mathrm{kg}$ of atropine sulfate was only equiponent to about $0.2 \mathrm{mg} / \mathrm{kg}$ or less of $\mathrm{C} 6$ in the blockade of adrenaline secretion. This indicates that the ganglionic blocking action of atropine is too little and does not explain the result that atropine after $\mathrm{C} 6$ caused appreciable inhibition of residual adrenaline secretion by stimulation of the splanchnic nerve. These results suggest that muscarinic receptors play a role in splanchnic-adrenal transmission in the rat.

In conclusion, the results of our experiments demonstrate that transmission of impulses through muscarinic receptors occurs in the adrenal medulla of the rat, though, likewise as in the dog and cat, this type of transmission is less prominent than that through nicotinic receptors.

Acknowledgment: The author expresses gratitude Dr. Y. Ogawa of the Shionogi Research Laboratory for many helpful discussions and suggestions.

\section{REFERENCES}

1) Feldeerg, W., Minz, B. And Tsudzimura, H.: J. Physiol. 81, 286 (1934)

2) Douglas, W.W. and Pols.ner, A.M.: Nature 208, 1102 (1965)

3) Kayanlp, S.O. ANd McIsaAC, R.J.: Br. J. Pharmacol. Chemother. 36, 286 (1969)

4) Yoshizaki, T.: Japan. J. Pharmacol. 23, 689 (1973)

5) Marley, E. and Paton, W.D.M.: J. Physiol. 155, 1 (1961)

6) Fink, L.D. ANd Cervoni, P.: J. Pharmacol. exp. Ther. 109, 372 (1953) 